\title{
En torno a los procesos de tradicionalización en los romances de ciego. La doncella muerta por su amante / El baile
}

\author{
Regarding the Processes of Making Tradition in «Romances \\ de ciego»: The Woman Dead by Her Lover / The Dance
}

\author{
Miriam PIMENTEL GARCÍA \\ (Universidad de Jaén) \\ miriampimentel90@gmail.com \\ ORCID ID: 0000-0003-4326-9918
}

\begin{abstract}
This paper intends to produce a comparative analysis of 49 oral samples of the kind of chapbook known as «romance de ciego» and titled The Woman Murdered by her Lover or The Dance. The main goal here is to acknowledge the traditionalizing mechanisms involved in the process of transmission of this motif. Also, the work will try to establish the degree to which there may appear various versions of a romance which was transmitted orally and on a late date, from a Chapbook. To do this, a detailed analysis of the level of discourse and on the plot configuration will be carried out, identifying links and similarities to other romance topics.
\end{abstract}

KEYWORDS: literature, loose folds, songs, Hispanic Ballads, oral tradition
RESUMEN. En el presente artículo se acometerá el análisis comparado de 49 muestras orales de un romance de ciego conocido como $\mathrm{La}$ doncella muerta por su amante o El baile. El principal objetivo de este trabajo es reconocer los mecanismos de tradicionalización que intervienen en el proceso de difusión de este tema y establecer hasta qué punto un romance difundido oralmente en fecha tardía a partir de un pliego puede presentar variantes. Para ello, se llevará a cabo un análisis detallado del plano del discurso y de la configuración de la intriga, y se localizarán engarces y contaminaciones con otros temas romancísticos.

PALABRAS-CLAVE: literatura oral, romancero de ciego, romancero de cordel, tradición oral

\section{INTRODUCCIÓN}

En este artículo se llevará a cabo el análisis comparado de las versiones de un romance de composición moderna con el fin de determinar los mecanismos de tradicionalización que se han puesto en marcha en su proceso de difusión. El objetivo principal es dilucidar si los romances de ciego modernos están expuestos a variación o si se mantienen inalterables, pues no es nada desdeñable la nómina de críticos que considera que son ajenos a los procesos de tradicionalización. Así, Catalán asegura en el prólogo a Salazar (1999: XXXI) que «las largas relaciones de pliego de cordel constituyen un género aparte del romancero y narraciones afines de tradición oral», ya que «a diferencia de los poemas de tradición oral, no están sujetos a reelaboración al pasar de memoria en memoria». También Atero Burgos asegura que «los romances de ciego son poemas cerrados y, por tanto, no susceptibles a los cambios y a la recreación de la colectividad. 
Los informantes los repiten miméticamente, sin alterarlos, con conciencia de autor ajeno» (Piñero Ramírez, 1996: 53).

Sin embargo, otros autores, como Díaz G. Viana, cuestionan estas afirmaciones y se preguntan: "¿acaso los "romances de ciego" no están también en la tradición oral de hoy y no han superado muchos de ellos más de cuatro y cinco generaciones de existencia?» (1983: 13-14). En la misma dirección, Escribano Pueo, Fuentes Vázquez y Romero López (1995: 12) aseguran que ambos tipos de romances poseen rasgos en común, como el grado de tradicionalidad. Partimos, por tanto, de opiniones contrapuestas: ¿son realmente los romances de cordel poemas cerrados? ¿Contienen variantes significativas?

Para realizar este análisis, he escogido un tema bastante difundido en España: $L a$ doncella muerta por su amante (IGRH: 5052; Manual, ${ }^{1}$ 206), del que se conserva una muestra en el Romancero Hispánico de la Fundación Menéndez Pidal, bajo el título de El baile y la referencia 5052. Teniendo en cuenta el grado de difusión del romance, el hecho de que solo haya una versión registrada en esta plataforma da una idea del escaso interés que este tipo de composiciones ha suscitado en el mundo académico hasta hace relativamente poco.

En cuanto al procedimiento de análisis empleado, he seguido el esquema propuesto por Mañero Lozano (en prensa), que en mi opinión permite clarificar los procesos de tradicionalización implicados en el corpus que nos ocupa; un corpus compuesto por 49 versiones ${ }^{2}$ procedentes de diversos puntos de España; en concreto, 5 versiones de la provincia de Córdoba, 8 de Jaén, 4 de Granada, 1 de Cádiz, 2 de Ciudad Real, 5 de Albacete, 2 de Toledo, 1 de Badajoz, 1 de Madrid, 1 de Ávila, 1 de Segovia, 1 de Zamora, 1 de León, 3 de Valladolid, 1 de Palencia, 5 de Burgos, 2 de La Rioja, 1 de Huesca, 2 de Santa Cruz de Tenerife y 2 de Las Palmas.

El primer apartado de este artículo está dedicado al análisis de las variantes del discurso presentes en el corpus. Para ello, se ha procedido a dividir el tema en secuencias narrativas y después se han cotejado las mimas en cada una de las muestras seleccionadas. El segundo epígrafe está consagrado al estudio de las variantes de la intriga, pues algunas versiones presentan sucesos que difícilmente pueden ser englobados dentro de las secuencias narrativas prototípicas del romance. Para finalizar, se han analizado las contaminaciones y engarces de este tema, cuya presencia es una muestra de su creciente grado de tradicionalización.

\section{ANÁLISIS DE LAS VARIANTES DEL DISCURSO}

Para llevar a cabo este análisis, he dividido el tema en secuencias, tomando como referencia las versiones más extendidas.

\section{Secuencia 1. Introducción en la que se adelanta el fatal desenlace}

Se trata de una secuencia formulada en dos versos donde se presenta la fecha y/o el lugar donde se desarrollan los hechos y se adelanta el fatal desenlace. Este tipo de introducción es muy frecuente en los romances de temática criminal debido a su afán de verosimilitud, y está presente en la mayoría de versiones recopiladas. Se omite en las muestras 2, 10, 20, 26, 27, 28, 30, 31, 39, así como las 14 y 42, estas dos extremadamente fragmentarias. Esta omisión puede ser signo del inicio del proceso de tradicionalización.

\footnotetext{
${ }^{1}$ Con la designación Manual se hace referencia a Atero Burgos (2003).

${ }^{2}$ Estas versiones aparecen transcritas al final del artículo.
} 
En lo tocante a la forma, las diferencias entre las versiones son más que palpables, tanto que ninguna de ellas coincide plenamente. De esta manera, en el primer verso, algunas solo indican el lugar donde se sitúa la acción. Entre ellas, existen varias que se inician de forma imprecisa con un: «Allá arribita, arribita / allá arribita en la era» (1; con variantes 4, 36); mientras que la versión 49 es más precisa y sitúa la acción «Allá arribita, arribita, / allá arribita en Almeña». Otras versiones sitúan la acción en una huerta, en la mayor parte de los casos, situada en Jaén: «En el vado de Jaén, / en la orilla de una huerta» (3; con variantes 6, 21 y 44, recogidas en las provincias de Jaén, Córdoba y Granada). Una versión segoviana también sitúa la acción en tierras jiennenses: «En la provincia Jaén, / señores, voy a contar» (33). Mucho más completa es la localización que ofrece la versión 41, donde se indica la localidad y la provincia a la que pertenece: «En la provincia de Cáceres, / en el pueblo la Tarleta» (41). En otras ocasiones, se introduce una llamada de atención al oyente: «En la cañá de Guartuna / ¿no saben lo que pasó?» (45), «Señores, voy a contar / lo que pasó en la Glorieta» (24), «En la provincia de Cuenca, / señores, voy a explicar» $(15,16,17)$.

Por otro lado, en algunas versiones solo se indica la fecha, aunque esta no suele coincidir. Los modelos más habituales son aquellos en los que se introduce una llamada de atención al público: «El veinticinco de mayo, / señores, voy a explicar» $(5,13)$, o «El día doce de mayo, / señores, voy a contar», que se puede rastrear con variantes mínimas en las versiones 9, 8, 18 y 46. Más singulares son las versiones 38: «El veinticinco de abril / cayó la bomba la reina», y 32: «El veintiuno de enero / una copla he de cantar». Las muestras 11 y 48 contienen una advertencia a las muchachas: «El veintiséis de diciembre, / muchachas, tener memoria» (11), y la versión 40 acerca la acción en el tiempo: «El veinticinco de mayo, / no hace mucho que pasó».

Por otro lado, hay muestras que explicitan tanto la fecha como el lugar donde ocurrieron los hechos. Es el caso de las versiones 17, 19 y 25. Mucho más tradicional es el inicio de la muestra 43: «Un domingo por la tarde, / en la puerta de la iglesia», pues no sitúa la acción en una fecha exacta.

En cuanto al segundo verso, se tipifican dos grandes grupos. En el primero se explica que un novio mató a su novia en plena juventud, y suele coincidir con los temas cuyos dos primeros versos presentan rima $e-a$, es decir, aquellos que no incluyen una advocación al público. La formulación más frecuente es la siguiente: «un novio mató a su novia / que es la flor de la violeta» $(3,6,21,41,24$ y 38). En otras versiones análogas, en lugar de la «flor de la violeta», se habla de la «flor de la canela» $(1,49,36,38)$. En ocasiones, estas flores se convierten en la causa de la muerte de la joven, así encontramos: «un novio mató a su novia / por la flor de la violeta (canela)» $(4,12,43,44$; con variantes, 24 y 25$)$.

El segundo grupo coincide con aquellos temas que presentan rima en -á en el primer verso, esto es, aquellos que incluyen la advocación al oyente. En estas versiones se suele especificar la razón por la que el novio mata a la novia. Una de las formulaciones más frecuentes es: «un novio mató a su novia / porque no quiso bailar» $(8,9,13,40)$, «por no salir a bailar» $(18,46)$, «por saber muy bien bailar» $(5)$ o «porque ha salido a bailar» (31).

Las versiones cuyos dos primeros versos presentan rima en $i$ - $a$, es decir, aquellas que incluyen una advocación a las mocitas, se formulan de la siguiente manera: «que por causa (culpa) de los bailes / un novio mató a su novia» (11 y 48). 
En la muestra 45, que rima en -ó, encontramos el siguiente verso: «que un novio mató a su novia / sin motivo ni razón». En este caso, el juicio moral es favorable a la muchacha, que se presenta libre de culpa aunque haya decidido asistir al baile.

En otras ocasiones, simplemente se anuncia lo que va a ocurrir sin desvelar la muerte de la joven. Así, el narrador trata de mantener el suspense a la vez que atrae a los oyentes: «En la provincia de Cuenca, / señores, voy a explicar // lo que le pasó (lo que ha ocurrido) a una joven / por saber muy bien bailar» (15, 16 y 17). Otras muestras similares desarrollan estos dos primeros versos de la siguiente forma: «Presten atención, señores, / si quieren escuchar // lo que le pasó a la Antonia / por saber muy bien bailar» (34; 7 y 35, con variantes). Estas versiones llevan la intriga al extremo, pues no explicitan el lugar ni la fecha en que suceden los hechos.

En la muestra 45 se añade una descripción de los personajes. A estos versos, que no aparecen en el resto de versiones y que probablemente sean un recuerdo de la versión original, los etiquetaré como 1A: «Antonio se llamaba él / y celoso por demás, // y ella se llamaba Lola / y era de guapa sin par».

Secuencia 2. Invitan a la joven a un baile. Sus padres no le permiten asistir, pero ella hace caso omiso de sus indicaciones

Esta secuencia se omite con mayor frecuencia que la primera, sobre todo en las versiones cuyo segundo verso explicita la causa de la muerte de la muchacha, en las que se prescinde de esta secuencia para evitar la redundancia. La secuencia suele formularse: «La invitaron al baile; / su padre no la dejó. // Sin permiso de su padre / ella al baile se marchó» (1; con variantes: 3, 41, 43 y 44). En algunas muestras es la madre la que le impide asistir $(19,38,43)$ o ambos progenitores (25).

Hay otros casos dignos de comentario. Así, en la versión 6 se enuncia: «y por cima de su padre / al baile se la llevó». Aparece, por tanto, un personaje que se la lleva a la fuerza al baile; el receptor presupone automáticamente que se trata del novio. En este caso la muchacha queda exenta de toda responsabilidad, pues el novio la ha obligado a asistir al baile. Por otro lado, en la muestra 21 se explica el método empleado por la muchacha para burlar la prohibición del padre: «Ella, que quería ir, / se tiró por el balcón». En la versión 12 se da a entender que la muchacha es rebelde, pues la madre, después de prohibirle asistir al baile, la somete a vigilancia: «un descuido de la madre, / que al baile se le marchó».

Secuencia 3. Todos los asistentes le tiran el sombrero. Su novio hace lo mismo, pero ella se niega a recogerlo

Su formulación más frecuente es: «Como era tan bonita, / le tiraban los sombreros. // Su novio le tiró el suyo / y no quiso recogerlo» $(3,8,9,43,45,21$; con variantes: 1, 2, $11,15,22,46$ y 32). En otras versiones, en lugar de explicitar que es el novio quien le tira el sombrero, se nos dice que es «Antonio» $(4,5,12,19,28,33,40,48$ y 49). No obstante, como en la mayor parte de estas versiones se ha anunciado previamente el crimen, el oyente identifica a Antonio con el criminal, por lo que no se produce la anagnórisis final. Solo la muestra 26 mantiene la identidad del novio oculta hasta el final. En otras versiones, en lugar de los sombreros, le tiran «los pañuelos» $(7,23)$.

Más variable se muestra el segundo verso de esta secuencia. Así, en la versión 10 encontramos: «el novio le tiró el suyo / y se lo dejó en el suelo». En las versiones 6, 44 y 47 se explica la razón por la cual la muchacha no recoge el sombrero; no es que no quiera, sino que le da vergüenza: «Su novio le tiró el suyo, / le dio vergüenza cogerlo». En una 
curiosa versión, es a ella a la que se le cae el sombrero bailando. El novio se lo devuelve, pero ella no quiere tomarlo: «Se le ha caído el sombrero, / no ha querido recogerlo; // se lo ha alcanzado su novio, / no ha querido recogerlo» (16). En este caso, el proceso de tradicionalización es más palpable, pues aparece una estructura paralelística. Por otra parte, en la muestra 13 no se explica la causa por la que le tiran los sombreros. En el plano formal, la versión 38 presenta una rima interna: «Y de guapita que iba, / todos le tiran el sombrero; // Antonio le tira el de él / y no lo quiso coger».

Por último, las muestras 34, 35 y 37 incluyen una somera descripción de los amantes en el primer verso, mientras que en el segundo explican los hechos. El desarrollo de esta secuencia difiere en las tres versiones: «Si su novio era guapo, / ella era mucho más; // si [...] el sombrero, / no le quiso levantar» (34). En la versión 35 el novio no le tira el sombrero, sino que se le cae y ella se niega a recogerlo: «El novio, que era muy chulo / y la novia mucho más, // se le ha caído el sombrero; / no se le ha querido dar». En la 37, los amantes intercambian sus papeles: «La joven, como era chula, / el sombrero le ha tirado, // y el joven, como era chulo, / no ha querido levantarlo» (37).

\section{Secuencia 4. El novio la amenaza de muerte}

Es la secuencia que sufre menos variaciones, e incluso se podría afirmar que es la principal, ya que aparece en la práctica totalidad de versiones. Es más, la 31 solo conserva esta secuencia y la 29 la introduce dentro de otro tema. En la formulación más frecuente encontramos la amenaza del novio introducida sin verbo dicendi: «—A la salida del baile, / me la tienes que pagar; // te he de cortar la cabeza / y la mano principal» (1, 3, 4, $6,11,15,16,19,22,28-30,32,33,42,44-47,49$; con variantes en 2, 13 y 26). En algunas ocasiones, la conjunción copulativa se sustituye por la disyuntiva «o» $(25,27,36$ y 37). En otras $(8,20,21,41$ y 43), se sustituye la copulativa por la preposición «con», de manera que la mano principal se convierte en el instrumento utilizado para llevar a cabo el crimen.

Los cambios más notables se producen, no obstante, en el segundo verso: «o te corto la cabeza / o te mato a puñalás» (10); «o te disparo tres tiros / o te mato a puñalás» (38). Algunas versiones parecen más cercanas al pliego y aún conservan el verbo dicendi $(5,17,40)$.

En ocasiones, se añade la respuesta de ella, que se muestra desafiante. A este añadido lo llamaremos 4A, y aparece en la versión 34: «-Ni te le levanto el sombrero / ni te vas a hacer pagar, // ni me cortas la cabeza / ni la mano principal—》. En la muestra 46 se conserva una respuesta similar, aunque en este caso la muchacha le asegura que será imposible que lleve a cabo su amenaza porque se irá del baile antes de que este termine.

En otras versiones $(23,44,45$, etc.), se incluye un segmento, que denominaré $4 \mathrm{~B}$, que da cuenta de cómo el novio no puede cumplir su amenaza al final del baile porque la muchacha está rodeada de gente.

En la muestra 18 se incluye un añadido que denominaré $4 \mathrm{C}$, en el que se narra cómo el novio decide marcharse a su casa porque al día siguiente tiene que madrugar.

En otro orden de cosas, las versiones 9, 14 y 34 sitúan la muerte de la joven a la salida del baile. Este final, quizá más cercano a la tradición oral, acorta la intriga considerablemente. Por otra parte, en las muestras 1 y 6 no se indica que el novio la matara la salida del baile, pero el oyente lo presupone, pues la muerte de la joven se sitúa justo después de la amenaza del muchacho. 
Secuencia 5. El joven acude a casa de su novia. Ella intenta que se aleje de allí, asegurándole que puede venir su hermano, pero él la asesina

Esta secuencia puede dividirse en tres partes: a) el novio acude a casa de la muchacha para cumplir su amenaza; b) la encuentra peinándose; c) la joven le pide que se vaya porque puede volver su hermano; d) el novio la mata.

a) El novio acude a casa de la muchacha para cumplir su amenaza

La formulación más frecuente es: «A otro día de mañana / Antonio se levantó, // fue a casa de su novia / a aprovechar la ocasión» $(15,16$ y 17; con variaciones, en 4, 5, 12, 21, 27, 40). Difiere más la formulación de la versión 33, que frente al tradicional «a otro día de mañana»o «a otra mañana temprano», prefiere el más conciso «a esto de las tres y media». Lo mismo ocurre con la versión 22: «Serían las seis de la tarde».

b) El novio encuentra a la joven peinándose

Las versiones que omiten la secuencia anterior se formulan de la siguiente manera: «Al otro día siguiente, / ella se estaba peinando» (2). Aparecen alteraciones en el nombre de la muchacha $(3,8,19$, etc.) También hay discordancias en la indicación temporal, ya que en lugar de «al otro día siguiente», podemos encontrar «al otro día de mañana» $(8,3$, 19, 43 y 44).

Por otra parte, las versiones que no omiten la secuencia 5a no incluyen referencia temporal en la 5b: «Al subir las escaleras, / Isabel se está peinando» $(15,16,17,37$ y 40). En otros casos, en lugar de Isabel aparece el nombre de Dolores, o simplemente «ella» $(4,5,12,27,33$ y 49). Por su parte, en la muestra 41 se aúna en un solo verso el motivo de la llegada del novio y la indicación de que la joven está peinándose: «Pero un día que fue a su casa, / ella se estaba peinando».

b1) El novio le anuncia su intención de matarla

Esta secuencia es infrecuente, quizá porque su existencia se remonte al pliego primigenio, lo que explicaría la aparición de verbos dicendi, tan extraños en los romances tradicionales: «Y, al subir las escaleras, / estas palabras le habló: // —Yo te mato y te mato, / yo te mato sin razón» (18; con variantes, 32$)$.

c) La joven le pide a su novio que se vaya porque puede volver su hermano

La forma en que se expresa es muy variada, si bien se pueden diferenciar claramente dos grandes grupos: aquel en que la joven suplica desesperadamente a su novio que se marche antes de que venga su hermano $(3,4,12,14,15,27,37,40$ y 49) y aquel en que la joven lo amenaza con la llegada del mismo (2, 8, 17 y 22, 19, 21, 33, 38 y 41).

c1) Respuesta desafiante del novio

La manera dispar de formular esta secuencia puede deberse a que se trata de una recreación tradicional, más que de un recuerdo del antiguo pliego, como podrá observarse al comparar las muestras 23, 26, 28, 45 y 47.

d) Asesinato de la muchacha

Tanto el arma utilizada como el modus operandi difieren en la mayor parte de las versiones. En algunas, el novio se descubre la capa y saca una navaja con la que apuñala a la joven $(2,26,41,43)$. Este tipo de formulaciones suelen dilatar la escena, dando cuenta 
de las partes del cuerpo donde la muchacha ha recibido las puñaladas: «la primera fue en el pecho, / la segunda en el ijar, // la tercera en el costado, / que es la que le hizo penar» (12; con variantes, 18, 27, 47).

En algunas ocasiones se indica la estancia donde ha sido asesinada. En las muestras 36, 44, 48 y 49 el criminal la apuñala sobre la cama, mientras que en la 15 lo hace en el portal, donde la deja tirada, y en la 23, en la sala. En cuanto al arma homicida, en ocasiones es una pistola (38) en lugar de una navaja o un puñal.

Las muestras 22 y 35 expresan esta secuencia de forma sintética en un solo verso: «Al subir la escalera, / dos puñaladas la da» (35). Se trata de un proceso de tradicionalización, al igual que el paralelismo presente en la muestra 17: "Ya se ha quitado la faja, / ya desenvaina el puñal, // ya la coge del cabello, / ya la empieza a destrozar».

d1) En sus últimos estertores, la joven acusa a su novio de haberla matado sin razón

En las versiones 11 y 12, el criminal le explica a la moribunda las razones de su asesinato. La muestra 13 es especialmente plástica, pues casi se puede observar cómo la sangre corre por el cuello de la joven mientras balbucea sus últimas palabras: «Ya se deforma la capa, / ya se desvaina el puñal, // la agarra de los cabellos, / la comienza a degollar. // Y estándola degollando / (y) estas palabras habló: // —No tengo más sentimiento / que me matas a traición-》. En la versión 24, la víctima le reprocha al asesino su acción antes de que este la apuñale, en lugar de hacerlo después, como ocurre con la muestra 25. En esta se aprecia un mayor grado de tradicionalización, pues se eliminan los verbos dicendi, además de establecerse el lugar de la acción de forma vaga recurriendo a una estructura paralelística: «al subir una escalera», «al subir otra escalera».

d2) El asesino se marcha de la escena del crimen

Esta secuencia se suele omitir. En las versiones 18 y 32 se expresa mediante una estructura paralelística, donde los rasgos de tradicionalización son ya patentes: «Ya se va aquel asesino, / ya se va aquel criminal» (18).

Secuencia 6. El padre encuentra el cadáver de la joven cuando vuelve a casa para comer

Se suele formular en tres versos: el primero sirve para indicar que el padre llega a almorzar o a merendar y la hora en que lo hace; el segundo cede la voz al padre, que se pregunta quién ha sido el criminal que ha matado a su hija, y en el tercero, este profiere una amenaza en contra del asesino.

En el primer verso, encontramos divergencias relativas a la hora indicada, que suele ser bastante precisa, aunque en ocasiones lo que se indica es el lapso de tiempo transcurrido entre el asesinato de la joven y la llegada del padre al hogar $(8,17,21,27$, 46). Otra de las diferencias radica en si el padre llega a «almorzar» o a «merendar».

En las versiones 16 y 17 se añade un verso en el que se explica que el padre encuentra el cadáver de su hija tirado en el portal. En el último verso de la muestra 16, en lugar de amenazar, el padre se pregunta: «¿Quién ha sido el criminal // que ha dado muerte a mi hija / y la ha tirado al portal?». Por otro lado, en el parlamento del padre de las versiones 13 y 21 hay un proceso de oralización claro, ya que se tiende a una estructura concéntrica:

Estando diciendo eso, su hermano se presentó:

— ¿Quién ha sido el atrevido que a mi hermana la mató?-.

A las tres o cuatro horas, su padre fue a merendar: 
- ¿Quién te ha matado, hija mía, quién ha sido el criminal?, que si lo cogiera ahora lo cogiera a puñalás (n. $\left.{ }^{\circ} 13\right)$.

En las muestras 28 y 40 es el hermano quien encuentra el cadáver de la doncella en lugar del padre, mientras que en la versión 35 es la madre la que descubre el macabro suceso.

\section{Secuencia 7. Amortajamiento y entierro}

En algunas versiones, como la 5, esta secuencia intercambia el orden con la última, en la que se narra la confesión del criminal. Suele estar formada por dos cuartetas: en la primera de ellas se cuenta cómo la joven es trasladada al suelo entre varios hombres - recordemos que en muchas versiones es asesinada en la cama- y el padre le tapa la cara con el pañuelo o el sombrero; en la segunda, la llevan a enterrar vestida de blanco y/o cubierta de rosas. La versión 3 es prototípica, mientras que la 41 y la 49 siguen un modelo paralelístico. En otras muestras, tan solo se selecciona el momento del amortajamiento (17, con variantes en 35). Por otra parte, en la versión 12 se inserta el planto del padre, al que sigue la contestación del novio y en la 13, un añadido que tiene visos de ser tradicional o provenir de alguna canción de estilo popular: «pide el novio unas tijeras / para cortarle el cabello, // para tener de su novia / toda su vida un recuerdo».

También parece tradicional el añadido de la muestra 42, donde la madre, que hasta ahora no había aparecido en el romance, es partícipe del dolor de su marido por la pérdida de su hija.

Por otro lado, el último verso de la muestra 47 reza así: «su novio, que estaba allí, / la tapó con el pañuelo». Y es que en esta versión se modifica el orden prototípico del romance: el padre vuelve a casa después de que hayan enterrado a la muchacha. Quizá por ello adquiera sentido que sea el novio el que la cubra con el pañuelo y no el padre.

Por último, me gustaría señalar la existencia de versiones que denotan su modernidad. Frente a los romances tradicionales, en estos aparece el mundo jurídico: el juez que levanta el cadáver $(21,45)$, la autopsia que revela el asesinato $(2,15)$, etc.

\section{Secuencia 8. Confesión del criminal}

Suele estar conformada por cuatro versos, en el primero de los cuales se narra cómo llaman al asesino para comprobar si conoce a su amada. El segundo suele contener la respuesta del novio asegurando que la conoce porque ha sido su novia; mientras que en los dos últimos confiesa el crimen y explica las razones que le llevaron a quitarle la vida:

Llamaron al criminal por ver si la conocía:

- ¿No queréis que la conozca? Si ha sido la prenda mía.

La maté porque la quise, porque otro no la quisiera.

Mujer que tanto he querido no quiero que otro la quiera $\left(\mathrm{n}^{\circ} 3\right)$.

Los dos primeros versos suelen mantenerse inalterables, mientras que sí plantean divergencias los otros dos, que suelen omitirse en numerosas ocasiones $(13,24,25,26$, $27,32,35,37,40,46)$, ya que, dependiendo de la versión, difieren las razones por las que el novio mata a la joven.

Entre las muestras que omiten los dos últimos versos, deben destacarse la 26 y la 35 que presentan tendencia a la concentricidad, rasgo muy presente en los romances tradicionales. En ellas se utilizan dos versos en lugar de uno para indicar que se ha llamado al criminal con el fin de interrogarlo sobre el crimen. 
Otras muestras se alargan con añadidos. Este es el caso de la n. ${ }^{\circ} 8$, donde el novio pide que lo ajusticien rápidamente: «Apretarme los cordones / y no me hagáis padecer, // que yo he matado a mi novia / y a mí me matan también»; y de la n..$^{\circ} 41$, donde se informa de que la joven se negó a acceder a sus deseos.

En algunos casos particulares, el novio no es llamado a declarar, sino que profiere dos últimos versos como contestación a los familiares o a la propia víctima (11 y 47). En la versión 21 se omite el verso en el que llaman al asesino, pues este también se encuentra en el cementerio, mientras que, por otro lado, se incrementa en un verso la respuesta del novio, recurriéndose de nuevo a la concentricidad. La versión 18 también es bastante peculiar, pues el novio muestra arrepentimiento por el crimen. Por último, la muestra 38 introduce una estructura concéntrica, donde cada uno de los miembros de la familia es interrogado acerca de la muerte de la joven.

\section{Secuencia 9. Fórmulas de cierre}

He decidido denominar así a las estructuras que se utilizan al final del romance y que pueden clasificarse en varios grupos. En algunas versiones, se combinan varias de ellas: a) El narrador pide que ajusticien a todo aquel que maltrate a una mujer. Es una de las más comunes y se formula así: «Si el alcalde de este pueblo / cumpliera con su deber, // cuatro tiros le pegara / (y) al que mata a una mujer» (5; con variantes, 10, 24, 26, 41, 43). b) Moraleja en la que se asegura que es imposible saber con qué tipo de hombre se ennoviarán nuestras hijas: "Un clavel cría una rosa, / y una rosa cría un clavel, // un padre cría a una hija, / sin saber para quién es: // si será para un granuja / o para un hombre de bien" (7; con variantes en 14, 17, 18, 20, 45, 46 y 48; con omisión del último verso en 14, 21 y 37). c) Las flores del cementerio se visten de luto y lloran por la muerte de la joven $(14,35,49)$. d) Despedida del padre en el camposanto $(2,12)$. e) La gente ya no puede pasear por la calle donde habita la madre del asesino (5, 15, 27 y 48). d) Advertencia de la madre, que pide al resto de padres que eduquen bien a sus hijos y que les otorguen libertad en cuestiones amorosas (19).

\section{VARIANTES DE LA INTRIGA}

Existen algunas versiones que presentan sucesos que difícilmente pueden ser englobados dentro de las secuencias narrativas que he señalado a lo largo del trabajo, y que quizá puedan ser vestigios del antiguo pliego, debido al escaso número de versiones que los conservan.

La primera de estas variantes, que denominaré P1, se suele situar justo antes de las fórmulas de cierre. En ella se narra cómo el criminal ofrece dinero para pagar el entierro de la víctima. Se conserva esta secuencia en las versiones 5 y 49, recogidas respectivamente en las provincias de Ciudad Real y Toledo. Ambas designan al criminal con su nombre completo (Antonio Fernández).

También podrían ser un recuerdo del pliego los cuatro últimos versos de la muestra 32, en los que se introduce una conversación entre el criminal y su madre (P2).

\section{CONTAMINACIONES Y ENGARCES CON OTROS ROMANCES}

Dado el creciente grado de tradicionalización de este romance, encontramos en las diferentes muestras rastreadas casos de contaminaciones y engarces con otros romances que comparten una temática similar. De esta manera, la muestra 22, recopilada en la provincia de Granada, presenta una interesante contaminación con el también tema de cordel María Antonia (Manual, 180), un romance muy extendido en Andalucía 
Oriental. Quizá el desencadenante para su unión sea el hecho de que ambos narran el desplante de una muchacha a su pretendiente.

Por otro lado, la versión 47 presenta un engarce con el tema La buenaventura del carnaval (Manual, 333), quizá porque ambas sitúan su acción en un baile y comparten la temática del amor frustrado.

Asimismo, encontramos casos de contaminación, como el de la versión 29, donde se observa la inclusión de la secuencia de la amenaza del novio en un tema de cordel que titularé María Jesús Manchado, en el que se narra la muerte de una joven a manos del novio rechazado. En el momento del ataque, ella exclama: "Yo a ti sabes que te quiero, / pero ya sabes que en casa // todos los días de fiesta / me están consumiendo el alma». Quizá sea la asociación de la expresión «días de fiesta» con la celebración de un baile la que propicia esta contaminación.

Por su parte, en la muestra 36 se aprecia una contaminación con el tema tradicional La doncella guerrera (IGRH: 0231; Manual, 31). Esta contaminación se ve propiciada porque la informante canta el romance con la misma melodía con que se suele cantar el tema tradicional.

Por otro lado, la versión 23 presenta contaminaciones con Corrido de Rosita Álvarez, cuyo tema es muy similar.

Las secuencias que favorecen más engarces y contaminaciones son las últimas. De esta manera, en la muestra 25 se produce una contaminación con el tema de cordel Atropellado por un tren (IGRH: 0156; Manual, 114) justo después de la secuencia 5, es decir, del asesinato de la joven a manos de su novio. En este caso particular, la víctima no muere en el acto, sino que queda malherida tras las tres puñaladas asestadas por su verdugo.

Sin embargo, la secuencia que más contaminaciones propicia es la séptima, esto es, el entierro de la doncella. Así, el desenlace de las versiones 34 y 37 presenta contaminación con el tema Muerte de la novia, y la muestra 44 en su desenlace toma prestados versos de Novio asesinado (IGRH: 0701; Manual, 25) y de Muerte de la novia.

De esta manera, aunque hayamos perdido el pliego original, podemos reconstruir una versión facticia del romance que se reduciría al siguiente esquema: 1, 1A, 2, 3, 4, 4A, 4B, 4C, 5, 5a, 5b, 5b1, 5c, 5c1, 5d, 5d1, 5d2, 6, 7, 8, P1, P2, 9.

\section{CONCLUSIÓN}

Se trata de un romance que probablemente se difundió mediante pliegos, pero cuya difusión ha alcanzado tal dimensión que sus rasgos de tradicionalización son más que considerables. No solo son notables las diferencias en el plano del discurso, sino incluso en el de la intriga, como he indicado anteriormente. Algunos de los rasgos más notables de este proceso de tradicionalización son la desaparición progresiva del narrador a favor de los personajes, cuyos parlamentos se introducen sin necesidad de verbos dicendi; el inicio de la acción in media res de algunas de las versiones (la 39, por ejemplo); la aparición de estructuras paralelísticas, la imprecisión de datos (los nombres de los personajes, lugares, fechas), así como los numerosos engarces y contaminaciones con otros temas.

Puede ser que esta tradicionalización esté condicionada por el contexto de difusión del romance. De esta manera, Amezcua (1991: 36) recoge un testimonio en el que la informante asegura que lo cantaba en el trabajo y Asensio García (2004: 99), el de una informante que asegura haberlo representado cuando niña cobrando entrada. 
En otro orden de cosas, estimo que la pervivencia de rasgos de literatura de pliego dan cuenta de su pasado como romance de cordel: el lenguaje periodístico, la intención de otorgarle verosimilitud mediante la inclusión de datos (nombres completos, días exactos, horas precisas), la demora del final con una moraleja, etc.

En definitiva, el análisis comparado de las variantes de este tema ha confirmado que también los romances de ciego modernos pueden estar sometidos a un proceso de oralización reciente, cuyo estudio se hace necesario. No obstante, en la actualidad es complicado llevar a cabo un estudio exhaustivo de algunos temas de ciego debido a la escasa atención que se le ha prestado al género en las campañas de recopilación. Por ello, creo que hay que intensificar el trabajo de campo mediante la realización de encuestas que tengan en cuenta también el romancero de ciego, así como activar el estudio de los procesos de tradicionalización del romancero de ciego de difusión oral, género inmerso en un flagrante proceso de desaparición.

\section{ANEXO. TRANSCRIPCIÓN DE LAS MUESTRAS MANEJADAS*}

[Versión 1: Belmez, Córdoba (CLO, 1288r)]

Allá arribita, arribita, allá arribita en la era, un novio mató a la novia en la flor de la canela. La invitaron al baile; su padre no la dejó.

Sin permiso de su padre ella al baile se marchó. Como era tan rebonita, le tiraron los sombreros, y el novio le tiró el suyo y no quiso arrecogerlo. A la salida del baile: - - Me la tienes que pagar. Te cortaré la cabeza y la mano principal-. Mira si la pagó bien, la cosió a puñalás.

[Versión 2: Fuente Obejuna, Córdoba $(C L O, 1287 \mathrm{r})]$

La convidaron al baile; su madre no la dejó.

Sin permiso de su madre ella al baile se marchó. Ella, como era tan guapa, le tiraban los sombreros. El novio le tiró el suyo y no quiso arrecogerlo. A la salida del baile: —Esta me la has de pagar. Te he de cortar la cabeza y la mano principal-. $\mathrm{Al}$ otro día siguiente, ella se estaba peinando.

-Retírate de aquí, Antonio, mira que llamo a mi hermano-.

Se desemboza la capa, ha sacado un navajón,

l'ha dado tres puñaladas al lado del corazón.

La echaron en la camilla para hacerle la istopsia;

toda vestida de blanco que parecía una rosa.

Llamaron al asesino, a ver si la conocía.

- ¿No queréis que la conozca si ha sido la novia mía?

Yo la maté porque quise y porque me dio la gana, la maté porque era mía, en ella nadie mandaba-. El padre que estaba allí se echó el sombrero a la cara: —AAdiós, hija de mi vida!, ¡adiós, hija de mi alma!

[Versión 3: La Rábita, Jaén (CLO, 0921r)]

* Las versiones 15,16 y 17 son muy similares, por lo que me ha resultado más operativo tomar como texto base la versión 17 y ofrecer a pie de página las variantes textuales de las muestras 15 y 16. 
En el vado de Jaén, en la orilla de una huerta, un novio mató a su novia, que era la flor de la violeta.

La convidaron a un baile; su padre dijo que no.

Sin premiso de su padre, en el baile se encontró.

Como era tan bonita, le tiraban los sombreros.

Su novio le tiró el suyo y no quiso arrecogerlo.

- iA la salida del baile me la tienes que pagar!

Te cortaré la cabeza y la mano prencipal-.

A otro día de mañana, la niña Isabel se está peinando:

-No subas, por Dios, Antonio, que puede venir mi hermano.

[Com.: Dice: "Ha subido y la ha cosido a puñalás". Y le dio siete puñalás. Y dice: ]

La cogieron entre dos, la pusieron en el suelo.

Su padre, que estaba allí, la tapó con un pañuelo.

La cogieron entre cuatro, la pusieron en la losa

toda vestida de blanco, que parecía una rosa.

Llamaron al criminal por ver si la conocía:

_ ¿No queréis que la conozca? Si ha sido la prenda mía.

La maté porque la quise, porque otro no la quisiera.

Mujer que tanto he querido no quiero que otro la quiera.

[Versión 4: Carrión de Calatrava, Ciudad Real (CLO, 0772r)]

Allá arribita, arribita, allá arribita en la peña,

un novio mató a su novia por la flor de la canela.

Como era tan bonita, le tiraron los sombreros

y Antonio le tiró el suyo y no quiso arrecogerlo.

-A la salida del baile me las tienes que pagar:

te he de cortar la cabeza y la mano principal-.

A otro día por la mañana Antonio se levantó

y fue en casa de Dolores a aprovechar la ocasión.

Al subir por la escalera Dolores se está peinando

y le dijo Antonio...

[Versión 5: Alcoba de los Montes, Ciudad Real (CLO, 0526r)]

El vinticinco de enero, señores, voy a explicar

un novio mató a su novia por saber muy bien bailar.

Como era tan rebonita la tiraban los sombreros;

Antonio la tiró el suyo y no quiso arrecogerlo.

A la salida del beile, se las empezó a jurar:

- Te he de cortar la cabeza y la mano principal-

A otro día de mañana, (y) Antonio se levantó,

y a la puerta de su novia (y) aprovechó la ocasión.

Y al subir las escaleras, Dolores se está peinando:

- Corre, vete, Antonio mío, no vaya a venir mi hermano-.

Se desenvuelve la capa y se ha sacado un puñal;

la agarró de los cabellos, la ha cosido a puñalás.

Y al bajar las escaleras, tres palabritas habló:

—No siento más, vida mía, que me has matado a traición-.

A eso de las doce y media sube su padre a almorzar:

— ¿Quién ha matado a mi hija, quién ha sido el criminal?

Si yo llego por un lao, le coso a puñalás-.

Ya la suben, ya la bajan, ya la ponen en el suelo,

y su padre que está allí la tapa con su pañuelo.

Ya la suben, ya la bajan, ya la ponen en la silla; 
llaman a Antonio Fernández por ver si la conocía:

- ¿No queréis que la conozca, si ha sido la novia mía?

No la maté por coraje ni porque otro la quería;

la maté por despreciarme lo mucho que la quería-

Ya la suben, ya la bajan, ya la ponen en la losa, ya la están amortajando, toda llenita de rosas.

Los primeros cinco duros que en la mesa se pusieron los puso Antonio Fernández para pagar el entierro.

Por la calle la Amargura ya no se puede pasar, porque vive doña Carmen, la madre del criminal. Si el alcalde de este pueblo cumpliera con su deber, cuatro tiros le pegara (y) al que mata a una mujer.

[Versión 6: Valdepeñas de Jaén (CLO, 0415r)]

En las huertas de Jaén, en una huerta primera, un novio mató a la novia que era la flor de la violeta. La convidaron a un baile y el padre no la dejó, y por cima de su padre al baile se la llevó.

Como era tan bonita, le tiraron los sombreros.

Su novio le tiró el suyo, le dio vergüenza al cogerlo. — iA la salida del baile me la tienes que pagar! Te has de cortar la cabeza y la mano principal-. Mira si se la pagó, mira si se la pagó que con un puñal dorado dos puñalás le dio.

[Versión 7: Vega de Santa María, Ávila (CLO, 0201r)] Atención pido, señores, para lo que voy a contar: lo que ha pasado a una joven por ir al baile a bailar. Como era tan bonita la tiraban los pañuelos. Su novio la tiró el suyo y no quiso recogerlo.

-El desprecio que me has hecho me le tienes que pagar, te cortaré la cabeza y no me desprecias más-.

A la mañana siguiente, Antonia se está peinando.

Se ha marchado en casa la novia con el puñal en la mano.

La ha dado dos puñaladas al lado del corazón; mira que sería grave, que la vida la costó.

Un clavel cría una rosa, y una rosa cría un clavel, un padre cría a una hija, sin saber para quién es: Si será para un granuja o para un hombre de bien.

[Versión 8: Jamilena, Jaén (CLO, 0057r)]

El treinta y uno de mayo, señores, os voy a contar, un novio mata a una novia porque no quiso bailar. Como era tan bonita le tiraban los sombreros; su novio le tira el suyo y no quiso arrecogerlo. — iA la salida del baile me la tienes que pagar!

¡Te he de cortar la cabeza con la mano principal!A otro día de mañana, Lola se estaba peinando.

-Antonio, vete de aquí, mira que llamo a mi hermano-. Al oír estas palabras, un tiro le disparó.

Ella se ha caído al suelo, de repente se murió.

Al medio día siguiente, sube el padre a merendar.

— ¿Quién ha matado a mi hija? ¿Quién ha sido este criminal?, 
que si lo hubiera pillado lo cosía a puñalás-.

La peinaron y la lavaron y la llevan a la losa

toda cubierta de flores, que parecía una rosa.

Llamaron al criminal por ver si la conocía.

- ¿No queréis que la conozca si ha sido la novia mía?

La maté porque la quise, pa que otro no la quisiera;

a la mujer de mi gusto no quiero que nadie la quiera.

Apretarme los cordones y no me hagáis padecer,

que yo he matado a mi novia y a mí me matan también.

[Versión 9: Jamilena, Jaén (CLO, 0050r)]

El dieciocho de mayo, señores, os voy a contar

que un novio mató a una novia porque no quiso bailar.

Como era tan bonita le tiraban los sombreros,

su novio le tiró el suyo y no quiso arrecogerlo.

- iA la salida del baile, me la tienes que pagar!

¡Te he de cortar la cabeza o la mano principal!- .

A la salida del baile, mira si se la pagó,

que un cuchillo que llevaba en el pecho le clavó.

[Versión 10: Arcos de la Frontera, Cádiz (Piñero Ramírez y Atero Burgos, 1986: n. ${ }^{\circ}$ 3.7)]

La convidaron a un baile, su madre no la dejaba,

sin permiso de sus padres para el baile se marchaba.

Como era tan bonita le tiraban los sombreros,

el novio le tíó el suyo y se lo dejó en el suelo:

- A la salida del baile me la tienes que pagar:

o te corto la cabeza o te mato a puñalás-.

La cogieron entre cuatro, la pusieron en el suelo,

su padre que estaba al lado la tapó con el pañuelo.

La quitaron del suelo, la pusieron en la acera,

su padre que estaba al lado la tapó...

Si la justicia de Roma cumpliera con su deber,

siete tiritos le diera al que mata a una mujer,

al que mata a una mujer, al que mata a una doncella

más bonita que un clavel, más blanca que una azucena.

[Versión 11: Cenizate, Albacete (Mendoza Díaz-Maroto, 1990: 261-262)]

El veintiséis de diciembre, muchachas, tener memoria,

que por causa de los bailes un novio mató a su novia.

Dolores, como es tan guapa, todos le tiran el sombrero;

se lo ha tirado su novio y no quiso recogerlo.

- A la salida del baile me las tienes que pagar:

te he de cortar la cabeza y la mano principal-

Al otro día por la mañana Antonio se levantó

y fue a casa de Dolores a aprovechar la ocasión.

- Vete, Antonio, de mi casa, no vaya a venir mi hermana-.

Se ha quitado la chaqueta y el puñal se lo ha enseñado;

la tiró contra la cama, cuatro puñalás le dio,

y la pobre doncellita estas palabras habló:

-No siento más en el mundo que me mates a traición.

- Si te mato o no te mato es porque otro no dijera,

que a mujer que yo he querido no quiero que otro la quiera. 
[Versión 12: Barrax, Albacete (Mendoza Díaz-Maroto, 1990: 262)]

El diecisiete de mayo, en la plaza de Talavera, un novio mató a la novia por la flor de la canela.

La invitaron al baile, su madre no le dejó;

un descuido de la madre, que al baile se le marchó.

Como era tan bonita, le tiraban el sombrero;

Antonio le tiró el suyo y no quiso recogerlo.

Y a la mañana siguiente Antonio se levantó

y fue a casa de la novia y a cogerla en ocasión.

Y a la entrada de la sala ella se estaba peinando:

-Antonio, vete de aquí, vaya y venga mi hermano-.

Se ha echado mano a la chaqueta, se ha sacado el puñal,

lo ha tirao contra la cama, le ha dado tres puñalás:

la primera fue en el pecho, la segunda en el ijar,

la tercera en el costado, que es la que le hizo penar.

Ya la suben, ya la bajan, ya la dejan en la fosa:

su padre, que estaba allí, la tapó con una rosa.

- iAdiós, hija de mi vida, hija de mi corazón:

no siento más en el mundo que hayas muerto a traición!

- Si ha muerto a traición no es porque otro lo dijera:

mujer que tanto he querido no quiero que otro la quiera.

[Versión 13: El Bonillo, Albacete (Mendoza Díaz-Maroto, 1990: 262-263)]

El vinticinco de mayo, señores, voy a explicar:

el novio mató a la novia porque no quiso bailar.

Todos le tiran las gorras, ya le tiran el sombrero

y Antonio se lo tiró y no quiso recogerlo.

- A la salida del baile me lo tienes que pagar:

te he de cortar la cabeza y la mano prencipal-.

$\mathrm{Y}$ al subir las escaleras (y) ella se estaba painando.

- No subas, Antonio mío, no vaya a venir mi hermano-.

Ya se deforma la capa, ya se desvaina el puñal,

la agarra de los cabellos, la comienza a degollar.

Y estándola degollando (y) estas palabras habló:

-No tengo más sentimiento que me matas a traición-.

Estando diciendo eso, su hermano se presentó:

- ¿Quién ha sido el atrevido que a mi hermana la mató?-.

A las tres o cuatro horas, su padre fue a merendar:

- ¿Quién te ha matado, hija mía, quién ha sido el criminal?,

que si lo cogiera ahora lo cogiera a puñalás-.

Llamaron al criminal por ver si la conocía:

- No querís que la conozca, si ha sido la prenda mía-.

Ya la suben, ya la bajan, ya la tienden en la mesa

toda vestida de blanco, que parecía una bella

que le hizo pecar a un santo.

Ya la suben, ya la bajan, ya la ponen en el suelo:

pide el novio unas tijeras para cortarle el cabello,

para tener de su novia toda su vida un recuerdo.

[Versión 14: Contreras, Burgos (Manzano Alonso, 2003: 443)]

$[\ldots]$

-Arrecoge ese pañuelo, que me le vas a pagar

a la salida del baile $\mathrm{y}$ a la puerta principal-. 
A la salida del baile, mira si se la pagó:

con un puñal de dos filos la cabeza la cortó.

Ya la cogen entre cuatro, por ver si la conocía:

- ¿No la voy a conocer, siendo mi novia querida?

Siendo mi novia querida, la maté con amor propio:

ya que no sea pa mí, que no se la lleve otro-.

Las rosas del cementerio todas se visten de negro

solo por ver a la Antonia cómo le hacen el entierro.

Las rosas del cementerio todas se visten de azul

solo por ver a la Antonia cómo le ponen la cruz.

Un rosal cría una rosa y una maceta un clavel,

un padre cría una hija y no sabe pa quién es.

[Versión 17 Testimonio base: Riocavado de la Sierra, Burgos (Manzano Alonso, 2003: 447).

Versión 15: Quintana del Pidio, Burgos (Manzano Alonso, 2003: 445). Versión 16: Coruña del

Conde, Burgos (Manzano Alonso, 2003: 446)]

En la provincia de Cuenca, señores, voy a explicar

lo que pasó ${ }^{3}$ a una joven por saber muy bien bailar.

Como era tan hermosa ${ }^{4}$, le tiraron el sombrero ${ }^{5}$

y, como ha sido su novio, ${ }^{6}$ no ha querido recogerlo.

Entonces la dijo Antonio ${ }^{7}$ : - Me la $^{8}$ tienes que pagar:

te he de cortar la cabeza y la mano principal-.

A otro día de mañana, Antonio se levantó

$\mathrm{y}^{9}$ fue $^{10}$ a casa de su novia a aprovechar la ocasión.

$\mathrm{Al}$ subir por $^{11}$ la escalera ${ }^{12}$, Isabel se está peinando

y le dice: - Vete, Antonio, ${ }^{13}$ vete ${ }^{14}$, que viene mi hermano-.

Ya se ha quitado la faja, ya desenvaina el puñal ${ }^{15}$,

ya la coge del cabello ${ }^{16}, \quad$ ya $^{17}$ la empieza a destrozar ${ }^{18}$.

$\mathrm{Y}$, al cabo de media hora ${ }^{19}$, viene su padre almorzar ${ }^{20}$

y se encuentra su hija tiradita en el portal.

— ¿Quién ha sido ese malvado ${ }^{21}$ ? ¿Quién ha sido el criminal?

$\mathrm{Si}$ supiera quién ha sido ${ }^{22}$, le quitara el puñalar ${ }^{23}$ -

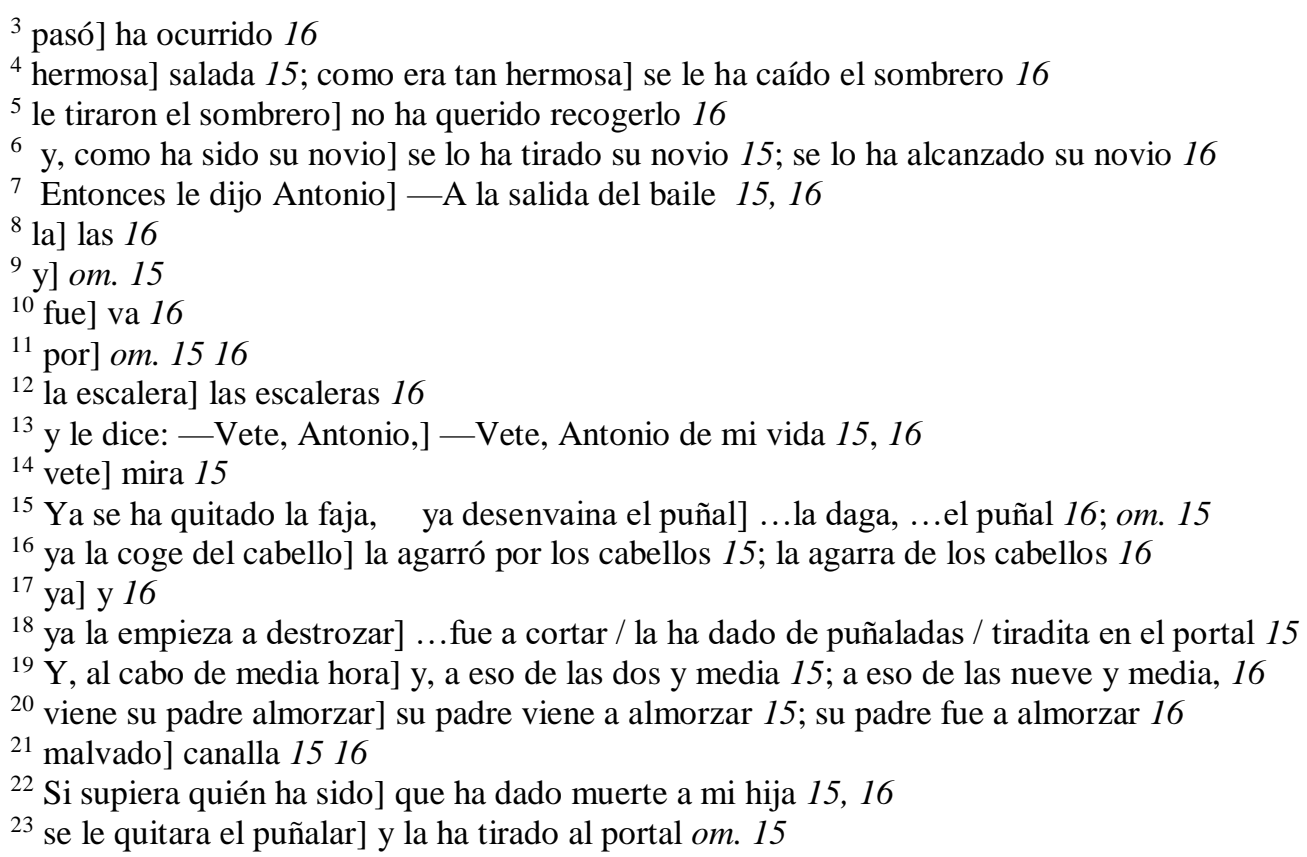


La cogieron entre cuatro ${ }^{24}$, la llevaron a una $\operatorname{losa}^{25}$, toda vestida de blanco ${ }^{26}$, que parecía una rosa ${ }^{27}$. El rosal cría la ${ }^{28}$ rosa, la clavelera e ${ }^{29}$ clavel, y un padre cría una hija $\operatorname{para}^{30}$ que la mate cruel $^{31}$.

[Versión 18: Arlanzón, Burgos (Manzano Alonso, 2003: 451)]

El día doce de mayo, señores, voy a contar, un novio mató a su novia por no salir a bailar. -A la salida del baile, me la tienes que pagar, te he de cortar la cabeza y la mano principalA la salida del baile Antonio se fue a acostar, que a otro día de mañana tenía que madrugar. Otro día de mañana, a casa su novia va $\mathrm{y}$, al subir las escaleras, estas palabras le habló: - Yo te mato y te mato, yo te mato sin razón-. -No subas ahora, Antonio, que ahora me estoy peinando. No subas ahora, Antonio, por si viniera mi hermano-. Ya se quita la chaqueta, ya desenfunda el puñal, le echa sobre la cama y le da tres puñalás. Primera le dio en el pecho, la segunda en..., la tercera en la cabeza, la que le hizo penar. Ya se pone la chaqueta, ya se marcha el criminal $\mathrm{y}$, a eso de las diez y media, su padre llega al portal:

- ¿Quién ha sido el atrevido, quién ha sido el criminal?

Si lo pillo en el acto, lo cuezo a puñalás-

Fueron a llamar a Antonio a ver si la conocía y él les dijo que sí, que era su novia querida: - Que me tiren siete tiros y también siete rayos, que yo he matado mi novia por cosa de poco daño-. Un rosal cría una rosa y una maceta un clavel, y un padre cría a una hija sin saber pa quién es, si es para hombre borracho o es para hombre de bien.

[Versión 19: Baza, Granada (Escribano Pueo, Fuentes Vázquez y Romero López, 1995: 67-68)] El día quince de mayo, lo que pasó en la placeta: un novio mató a una novia que era la flor de la violeta. La convidaron a un baile y su madre no la deja. Sin permiso de su madre en el baile se encontraba. Como era tan bonita, le tiraban los sombreros; Antonio le tiró el suyo y no quiso recogerlo. -A la salida del baile, me la tienes que pagar; te he de cortar la cabeza y la mano principal-. A otro día de mañana, Rosario se está peinando, y le dice: - Vete, Antonio, que puede venir mi hermano-

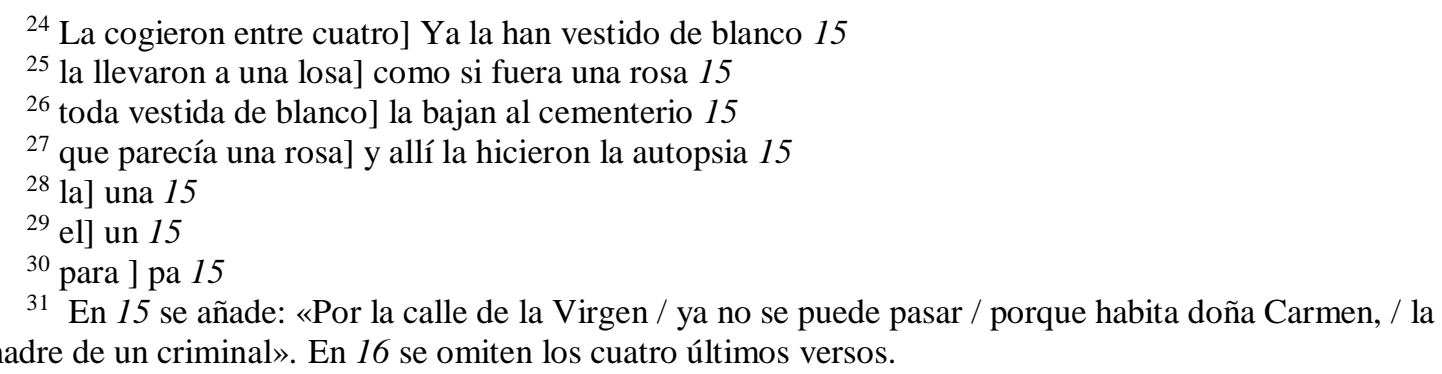


Se deslió de la capa y se sacó un puñal $\mathrm{y}$, al lado del pecho, tres puñaladas le da. A otro día el padre, que estaba en el entierro, la tapó con el pañuelo,

y Antonio, que estaba allí, la tapó con el sombrero.

Y su madre decía:

-Padres que tengáis hijos, dadles muy buena enseñanza, no le quitéis el querer porque el querer los mata.

[Versión 20: Colomera, Granada (Escribano Pueo, Fuentes Vázquez y Romero López, 1995: 6869)]

Como era tan bonita tos le tiran el sombrero.

Antonio le tiró el suyo y no quiso recogerlo.

-A la salida del baile, me la tienes que pagar;

te he de cortar la cabeza con la mano principal-.

$\mathrm{Y}$ a la mañana siguiente, Antonio se levantó,

fue a la puerta de la novia a aprovechar la ocasión.

Quitándose la chaqueta y tirando del puñal,

en el ladito derecho, le ha dado tres puñalás.

A la una de la tarde, vino el padre a merendar:

— ¿Quién ha matado a mi hija? ¿Quién ha sido el criminal?

Que si ahora lo pillara, lo cosía a puñalás-.

Un rosal cría una rosa, una maceta, un clavel,

y un padre cría una hija sin saber para quién es;

si es para perro judío o es para un hombre de bien.

[Versión 21: Granada (Escribano Pueo, Fuentes Vázquez y Romero López, 1995: 69-71)]

En el río de Jaén, en el río hay una huerta,

mató su novio a la novia y es la flor de la violeta.

La convidaron al baile, su padre no la dejó.

Ella, que quería ir, se tiró por el balcón.

Como era tan bonita, le tiraban el sombrero.

Su novio le tiró el suyo y no quiso recogerlo.

-A la salida del baile, Me la tienes que pagar,

te he de cortar la cabeza con mi mano prencipal-.

A otra mañana temprano, Antonio se levantó,

se fue a casa de la novia pa aprovechar la ocasión.

La novia se está peinando a la entrada de la sala:

-iVete, Antonio, vete, Antonio, mira que llamo a mi hermano

y a ti te quiere pegar y a mí me va a meter mano!- .

Ha subido otra escalera y ha sacado el puñal;

le ha cortado la cabeza con su mano principal.

A las tres horas siguientes, vino el padre a merendar:

— ¿Quién ha sido este granuja, quién ha sido el criminal?

Si ahora mismo lo cogiera, lo cosía a puñalás.

Que se traigan la camilla y también el justicial,

que se traigan la camilla y también el criminal,

que mi hija no ha sido muerta, que la han matado a puñalás-.

La pusieron en la losa, toda vestida de blanco

y le preguntan al novio que si él la conocía:

- ¿Cómo queréis que no la conozca si ha sido la prenda mía?

¿Cómo queréis que no la conozca si era lo que más quería?

La maté porque yo quise, porque otro no la quisiera, 
amor que te he querido tanto ni quiero que otro la quiera-. Un rosal cría una rosa, una maceta un clavel, y un padre cría a una hija sin saber para qué.

[Versión 22: Haza Mora, Albuñol, Granada (Escribano Pueo, Fuentes Vázquez y Romero López, 1995: 71-72)]

-María Antonia, tú estás loca, no sabes lo que has hecho, despreciar a un primo hermano para querer a un forastero. -No lo desprecio por pobre ni tampoco por la edad, lo desprecio porque tiene una larga enfermedad.

- Si las ventanas hablaran y los balcones también, te diría, María Antonia, mi enfermedad cuál es-. Como era tan bonita, le tiraron los sombreros. Su novio le tiró el suyo y no quiso recogerlo. A la salida del baile: - - Me la tienes que pagar; te he de cortar la cabeza y la mano principal-. Juan Antonio llegó a su casa y se sentó en el sillón; le pidió a su madre agua $\mathrm{y}$, al momento, se la dio: - ¿Qué te pasa, hijo querido? ¿Qué te pasa, hijo del alma?

- Que me ha dicho María Antonia que conmigo no se casa.

Cinco duros tiene míos, madre, vaya usted a por ellos; ya que me ha robado el alma, que no me robe el dinero-. Serían las seis de la tarde, se levanta el criminal y se ha liado en su capa a cogerla descuidá.

Cuando llegó el caballero, ella se estaba peinando y le ha dicho María Antonia: - - Vete, que viene mi hermano-.

Se ha desliado de su capa y tres tiros le dio.

[Versión 23: Los Realejos, Santa Cruz de Tenerife (Trapero, León Felipe y Monroy Caballero, 2016: 442-443)]

Año de mil novecientos, presente lo traigo yo.

Año de mil novecientos, Rosita virgen murió.

Y su padre le decía: - - Rosita, hoy no se sale-.

Y sin permiso de su padre Rosita estaba bailando.

A Rosita, como es más guapa, todos le tiran pañuelos.

Antonio le tiró el de él y no quiso recogerlo.

- Rosita, no me hagas eso, que la gente lo va a notar.

- Que lo note o no lo note, contigo no he de bailar.

- A la salida del baile, te las voy a cobrar;

o te abro la cabeza o te mato a puñaladas-.

A la salida del baile, no se las pudo cobrar, porque estaba con sus amigas y un guardia municipal.

A la mañana siguiente, temprano se levantó y a la casa de Rosita Antonio marchó.

-Antonio, marcha tranquilo, que llamo a mi hermano.

-A mí no me importa que lo llames o lo dejes de llamar,

lo que me hiciste anoche te la tengo que cobrar-.

La agarró por el bracito y a la sala se la llevó;

al lado del corazón, seis puñaladas le dio.

Con los gritos de ella, la gente se acercó:

— ¿Quién ha sido el asesino? ¿Quién ha sido el criminal?

- Yo he sido el asesino y yo he sido el criminal,

yo fui quien mató a Rosita porque no quiso bailar- 
Rosita estaba en la mesa y la pusieron en el suelo, y el padre, que está al lado, la tapó con el pañuelo.

- Si el alcalde de este pueblo no tuviera piedad de ella, le daría cuatro tiros al que mató a esta mujer.

-Yo merezco cuatro tiros, cuatro tiros y muchos más;

yo fui quien mató a Rosita porque no quiso bailar.

No la maté porque quise ni porque ella me quisiera, la maté porque era mía y no pude gozar de ella-.

Ahora Rosita está pidiendo clemencia a Dios, y Antonio está dando su nueva declaración.

[Versión 24: La Victoria de Acentejo, Santa Cruz de Tenerife (Trapero, León Felipe y Monroy Caballero, 2016: 444)]

Señores, voy a contar lo que pasó en la Glorieta: un novio mató a su novia por una flor de violeta.

Al subir las escaleras, estas palabras le dijo:

- Tú me matas porque quieres, yo no te he hecho motivo-

Al bajar las escaleras, tres puñaladas le da; cayó redondita al suelo sin decir: «iVálganos Dios!» La cogieron entre cuatro, la pusieron en la losa, toda vestida de blanco que parecía una rosa. La quitaron de la losa, la pusieron en el suelo, su padre, que estaba enfrente, la tapó con un pañuelo. Llamaron al criminal por ver si la conocía: - iNo la voy a conocer si esta fue la prenda mía! Si el alcalde de este pueblo cumpliera con su deber tres puñaladas le diera al que mató a esta mujer.

[Versión 25: Calahorra, La Rioja, (Asensio García, 2004: 99)]

A veinticinco de abril, lo que pasó en Galilea: un novio mató a su novia por la flor de la bandera. La convidaron al baile, sus padres no la dejaban. Sin permiso de sus padres, ella en el baile se entraba. -A la salida del baile, me la tienes que pagar; te he de cortar la cabeza o la mano principal-. Al subir una escalera, estas palabras le habló: — Tú me matas. —Yo te mato. - — Tú me matas sin razón-. Al subir otra escalera, tres puñaladas le dio; ¡mira qué tres puñaladas!; ella en el suelo cayó. La cogen en la camilla, la llevan al hospital, $y$ en el hospital le dicen que no la pueden curar.

- Si no me pueden curar, que me tiren cuatro tiros, que yo no puedo vivir con el corazón herido-. Llamaron al criminal, a ver si la conocía:

—QQué hacer sino conocer que ha sido la novia mía!

[Versión 26: El Rincón, Santo Tomé, Jaén (CLO, 1442r)]

A la salida del baile, tos le tiran el sombrero, y Antonio le tira el suyo y no quiso recogerlo. -A la salida del baile, me la tienes que pagar; te he de cortar la cabeza y la mano principalOtro día por la mañana, Antonio se levantó y fue a casa de Dolores, Dolores se está peinando. 
-Anda, vete de aquí, Antonio, por si viniera mi hermano.

-Yo no le temo a tu hermano ni tampoco a ningún hombre-.

Se ha echao mano al bolsillo y se ha sacado un puñal,

entre la carne, a Dolores seis puñalás le pegó.

Llamaron al endebido, llamaron al criminal,

llamaron al endebido por ver si la conocía:

-Sí, señor, que la conozco, que ha sido la novia mía-.

Si el alcalde de este pueblo cumpliera con su deber,

siete tiros se merece (y) el que mata a una mujer,

el que mata a una mujer sin tener culpa ninguna.

[Versión 27: Almansa, Albacete (Ferrer-Sanjuán y Bonete Piqueras, 1993: 105)]

Como era tan bonita, todos le tiran los sombreros.

Antonio le tira el suyo y no quiso arrecogerlo.

- A la salida del baile me la tienes que pagar;

te he de cortar la cabeza o la mano principal-.

Y a la salida del baile ya no la pudo lograr.

Y a otro día en la mañana, Antonio se levantó,

fue a casa de su novia y aprovechó la ocasión.

$\mathrm{Al}$ subir las escaleras, Dolores se está peinando:

- ¿Dónde vas, Antonio mío? No vaya a venir mi hermano-.

Levantándose la capa y enseñándole el puñal,

la cogió de los cabellos, le ha dado tres puñalás:

una se la dio en el pecho, la otra en el corazón.

A las tres horas y media, su padre vino a almorazar:

— ¿Quién te ha muerto, hija mía? ¿Quién ha sido el criminal?-.

Llamaron al criminal por ver si la conocía:

- ¿No queréis que la conozca si ha sido la novia mía?-.

Por la puerta de la Gloria ya no se puede pasar

porque vive doña Carmen, la madre del criminal.

[Versión 28: Alpera, Albacete (Ferrer-Sanjuán y Bonete Piqueras, 1993: 106)]

La convidaron a un baile, su padre no la dejaba.

Sin permiso de sus padres, en el baile se encontraba.

Como era tan bonita, le tiraban los sombreros.

Antonio le tiró el suyo y no quiso recogerlo.

- Y a la salida del baile, me las tienes que pagar;

te he de cortar la cabeza y la mano principal-.

A la salida del baile, como tanta gente había,

Antonio le dio vergüenza; lo dejó pa otro día.

Otro día de mañana, Antonio se levantó,

fue a casa de su novia y aprovechó la ocasión

$\mathrm{y}$, al subir las escaleras, ella se estaba peinando.

${ }_{-i V e t e}$ Antonio, vete, Antonio, mira que vendrá mi hermano!

- Mientras tu hermano no venga, me la tienes que pagar;

te he de cortar la cabeza y la mano principal-.

A las ocho en punto, en punto, vino su hermano a almorzar:

- ¿Quién ha sido el asesino, quién ha sido el criminal?,

que si ahora le pillara, le daba cien puñalás-.

Llamaron al asesino por ver si la conocía:

— ¿Cómo no queréis que la conozca si ella ha sido novia mía? 
La maté porque la quise, pa que nadie la quisiera, que como yo la he querido, no habrá hombre que la quiera.

[Versión 29: Santa Cruz del Retamar, Toledo (ATO, 00124 03)]

El catorce de septiembre, por ser día señalado, ha matado este criado a María Jesús Manchado. María Jesús marcha a la plaza y su padre en el balcón, meneando la cabeza, que le dijera que no.

Ella, por hacerle caso, pa su casa se marchó y, a la puerta de su casa, al encuentro le salió. La ha tirado del vestido y en el suelo la cayó: -Y ahora dime si me quieres, María Jesús, dímelo. -Yo a ti sabes que te quiero, pero ya sabes que en casa todos los días de fiesta me están consumiendo el alma. -A la salida del baile, me la tienes que pagar; te he de cortar la cabeza y la mano principal-. Y lo cogen en el carro, lo llevan como un ladrón, amarrado con cadenas, lo llevan a la prisión. A la puerta de Rogelio, el carro se le paró pa que viera Cipriano a paloma que mató.

[Versión 30: Medina del Campo, Valladolid (ATO, 00133A 29)]

-A la salida del baile, me las tienes que pagar; te he de cortar la cabeza o la mano principal-.

[Com. 1: Había una niña muy guapa, la tiraban los sombreros.]

Estaba en el baile, la tiraban los sombreros, y se le ha tirado su novio y no ha querido recogerlo.

[Com. 2: Luego la dice el novio:]

-A la salida del baile, me las tienes que pagar; te he de cortar la cabeza o la mano principal-.

[Com. 3: Y luego la mata y yo ya no me acuerdo de más.]

[Versión 31: Villalumbroso, Palencia (ATO, 00213 28)]

-A la salida del baile, me las tienes que pagar-.

Con el puñal en la mano [Com.: No me acuerdo]

[Versión 32: Valladolid (ATO, 00339 29)]

El veintiuno de enero una copla he de cantar, que un novio mató a su novia porque no ha salido a bailar.

Como era tan bonita le tiraban los sombreros. Su novio le tiró el suyo y no quiso recogerlo. -A la salida del baile, me la tienes que pagar; te he de cortar la cabeza y la mano principalA otro día por la mañana, Antonio se levantó, marcha en casa de su novia pa pillarla en ocasión. Al subir las escaleras, estas palabras habló:

-No siento más en el mundo que te mato sin razón-. $\mathrm{Y}$, al entrar en la sala, ella se estaba peinando:

-Retírate ya tú, Antonio, no vaya a venir mi hermano-. Se ha quitado la chaqueta, desenvaina su puñal, se ha echado sobre la cama y le dio tres puñalás. Ya se va aquel asesino, ya se va aquel criminal. 
Y a la misma doce en punto, fue su padre pa almorzar:

— ¿Quién ha sido el asesino? ¿Quién ha sido el criminal?

Si aquí mismo lo cogiera, lo cosía a puñalás-.

La quitaron de la cama para ponerla en el suelo.

Antonio, que estaba allí, la tapó con su pañuelo.

La quitaron del suelo para llevarla a la fosa,

toda vestida de blanco, que parecía una diosa.

Llamaron al criminal por ver si la conocía:

- ¿Quieres que no la conozca si ha sido la novia mía?

- Madre, deme usted un pañuelo, que me lo ponga de luto, que le he quitado la vida la mujer que quería tanto.

- Vete por ahí, ladrón; vete por ahí, criminal.

Tienes que pagar la muerte, la muerte de Laura Gómez.

[Versión 33: Villoslada, Segovia (ATO, 00352 02)]

En la provincia Jaén, señores, voy a contar:

un novio mató a su novia por no salir a bailar.

Como era tan bonita, la tiraban el sombrero,

Antonio la tiró el suyo y no quiso recogerlo:

- A la salida del baile, me la tienes que pagar;

te he de cortar la cabeza y la mano principal-.

A esto de las tres y media, Antonio se levantó,

por el huerto de su novia, a pillarla en ocasión.

Isabel se está peinando en el centro de la sala:

-No entres, Antonio mío, mira que llamo a mi hermana-.

Se desenvolvió la capa y la ha enseñado un puñal

y la ha agarrado del cuello, como quererla matar.

A eso de las tres y media, subió el padre a merendar:

— ¿Quién ha matado a mi hija? ¿Quién ha sido el criminal?

Si le pillara yo ahora le daría cien puñalás.

[Versión 34: Santiago de la Requejada, Zamora (ATO, 000369 02)]

Presten atención, señores, si quieren escuchar

lo que le pasó a la Antonia por saber muy bien bailar.

Si su novio era guapo, ella era mucho más,

si [...] el sombrero, no le quiso levantar.

-Me levantas el sombrero y me vas a hacer pagar:

te he de cortar la cabeza y la mano principal.

-Ni te le levanto el sombrero ni te vas a hacer pagar,

ni me cortas la cabeza ni la mano principal-.

Mira si será verdad, mira si será verdad,

que a la salida del baile, la cabeza le cortó.

La cogieron entre cuatro y al sepulcro la llevaron,

el vestido que llevaba era de sangre bañado,

el vestido que llevaba era de brocal de seda,

pero no valía nada pa lo guapa que ella era.

Hasta el mismo cementerio y hasta el mismo enterrador sacó su pala y el pico y hasta el novio entierro oyó.

Cuando la meten al hoyo, mi pañuelo le tiré

porque no coma la tierra boquita que yo besé,

boquita que yo besé, boquita que yo besaba.

Cuando la meten al hoyo, mi pañuelo le tiraba.

Preso en la cárcel de Asturias, preso en la de Santander, 
preso por toda mi vida por una mala mujer.

[Versión 35: Villabrágima, Valladolid (ATO, 0039 06)]

Atención pongan, señores, para poder explicar

lo que ha pasado a una joven por saber muy bien bailar.

El novio, que era muy chulo y la novia mucho más,

se le ha caído el sombrero; no se le ha querido dar.

- ¿Me levantas el sombrero? Me las tienes de pagar-.

Al subir por la escalera, dos puñaladas la da.

Su madre llegó al momento, la tapó con el pañuelo.

Llamaron al criminal y se presentó al momento.

Llamaron al criminal por ver si le conocía.

- ¿Cómo no he de conocerla siendo Antonia novia mía?-.

Ya la cogen entre cuatro, a la losa la llevaron,

iba vestida de blanco, que parecía una rosa.

Las flores del cementerio todas ya visten de luto,

están mirando a la Antonia que la meten al sepulcro.

[Versión 36: Carabanchel, Madrid (ATO, 00429 05)]

Allá arribita, arribita, allá arribita en la aldea,

un novio mató a su novia que era la propia canela.

La convidaron al baile; su madre no la dejó.

Sin permiso de su madre ella al baile se marchó.

-No vayas, hija, no vayas, que te van a conocer;

tienes el pelito largo y carita de mujer.

- Si tengo el pelito largo, madre, me lo cortaré

y, después de bien cortado, yo al baile me iré-.

Como era tan rebonita, la tiraban el sombrero.

Antonio la tiró el suyo y no quiso recogerlo.

-A la salida del baile, me la tienes que pagar;

te he de cortar la cabeza o la mano principal.

[Versión 37: Navianos de la Vega, León (ATO, 00598 28)]

$[\ldots]$

Lo que sucedió a una joven por saber muy bien bailar.

La joven, como era chula, el sombrero le ha tirado,

y el joven, como era chulo, no ha querido levantarlo

-A la salida del baile, me la tienes que pagar:

o te corto la cabeza o la mano principal-.

Y al otro día siguiente, Antonio se levantó.

Se dirige hacia la puerta y aprovecha la ocasión.

Sube la escalera arriba, Isabel se está peinando:

-No subas, Antonio mío, mira que viene mi hermano-.

$\mathrm{Y}$ a eso de las doce en punto, llega el padre a merendar:

— ¿Quién ha matado a mi hija, quién ha sido el criminal?-.

Llamaron al criminal por ver si la conocía:

- ¿Cómo no va a conocerla siendo ella la prenda mía?-

Una rosa es una rosa y una maceta, un clavel.

Y llevaba una caja de esas ricas lentejuelas,

pero no valía nada pa lo guapa que ella era.

Mira si sería guapa que hasta el mismo enterrador,

tiró la herramienta y dijo: - - A esta no la entierro yo. 
[Versión 38: La Oliva, Fuerteventura (Trapero, 1991: 269-270)]

El veinticinco de abril cayó la bomba la reina,

el novio mató a la novia que era la flor de la canela.

La invitaron para el baile, su madre no la dejó

y, sin permiso de su madre, para el baile se marchó.

Y de guapita que iba, todos le tiran el sombrero;

Antonio le tira el de él y no lo quiso coger.

-A la salía del baile, te las tengo que cobrar:

o te disparo tres tiros o te mato a puñalás-

Y a otro día siguiente, se estaba ella peinando:

- Quítate de ahí, Antonio, mira que llamo a mi hermano-.

Antonio, por obediente, de la puerta se quitó.

Dispara a Amelia tres tiros que muertita la dejó.

Llamaron a su padre por ver si la conocía.

- ¿No la voy a conocer, si esta es mi niña querida?-

Llamaron a su madre por ver si la conocía:

- ¿No la voy a conocer, si esta es mi hija querida?-.

Llamaron a su hermano, por ver si la conocía.

— ¿No la voy a conocer, si esta es mi hermana querida?-

Llamaron al criminal por ver si la conocía:

— ¿No la voy a conocer, si esta es mi novia querida?-

La recogen en la camilla, la llevan al camposanto,

parecía una paloma toda vestida de blanco

En el cementerio está toda llena de coronas,

pidiéndole al Dios del cielo que se la lleve a la gloria.

[Versión 39: Agüimes, Gran Canaria (ALOC, https://mdc.ulpgc.es/cdm/singleitem/ collection/asmtloc/id/4060/rec/3)]

Al subir las escaleras, ella se estaba peinando:

-Antonio, vete de aquí, mira que te ve mi hermano-.

Él se levanta, la desata y se ha sacado un puñal;

se ha ido derecho a ella, la ha cosido a puñalás.

A las ocho y media en punto, llega el padre a merendar:

-Hija mía, ¿quién te ha matado?, ¿quién ha sido el criminal?

Que si hubiese estado aquí, la alma se iba a puñalás.

[Versión 40: Benasque, Huesca (FMT, M28-662)]

El veinticinco de mayo, no hace mucho que pasó,

un novio mató a una novia porque no quiso bailar

$\mathrm{y}$, como era tan bonita, le tiraban el sombrero;

Antonio le tiró el suyo; no lo quiso recoger.

A la salida del baile le dijo: - Te has de acordar:

te he de cortar la cabeza y la vena principal-.

A la mañana siguiente, Antonio se levantó

y fue a casa su novia a aprovechar la ocasión.

Al subir las escaleras, Isabel se está peinando:

—DDónde vas, Antonio mío?, que puede subir mi hermano-.

Ya se ha quitado la capa, ya le ha enseñado un puñal,

ya la coge de los pelos, ya le ha clavado el puñal.

$\mathrm{Al}$ son de la media hora, su hermano sube a almorzar.

—QQuién ha sido el asesino? ¿Quién ha sido el criminal?-

Llamaron al asesino por ver si la conocía: 
- ¿No la voy a conocer si ha sido la prenda mía?-. Si el alcalde de este pueblo cumpliera con su deber, que le peguen cuatro tiros al que mató a esta mujer. Ya la han vestido de blanco, ya la llevan a enterrar toda cubierta de flores y una caja de cristal.

[Versión 41: Castilblanco, Badajoz (Cid, 1974: 497-498)]

En la provincia de Cáceres, en el pueblo la Tarleta, un novio mató a su novia que es la flor de la violeta. La convidaron al baile, su padre no la dejó. Sin licencia de sus padres ella al baile se marchó. Como era tan rebonita, la tiraban el sombrero, su novio la tiró el suyo y no quiso arrecogerlo. -A la salida del baile me las tienes que pagar; te he de cortar la cabeza con la mano principal-. A la salida del baile no la quiso decir na porque había mucha gente y le iban a sujetar. Pero un día que fue a su casa, ella se estaba peinando:

-Retírate de ahí, Antonio, mira que llamo a mi hermano-.

$\mathrm{Al}$ decir esas palabras, ha sacado un navajón, la ha dado una puñalada en mitad del corazón. Y la quitaron de allí y la echaron en el suelo. Su padre, que estaba allí, la echa a la cara un pañuelo. Y la quitaron de allí y la pusieron en la losa, toda vestida de blanco, que parecía una rosa. Llamaron al criminal por ver si la conocía: - ¿No queréis que la conozca si ha sido la prenda mía?

Yo la maté porque quise y porque me dio la gana; mujer que yo quería tanto, no quería que otro la amara, no quería que otro la amara ni de que otro gozare, que quería gozarla yo, Madre mía de los Pilares-. Si el gobernador de aquí cumpliera con su deber, siete tiritos merece el que mata a una mujer.

[Versión 42: Espiel, Córdoba (Moreno Moreno, 2016: 657)] le tiraron los sombreros.

Él le tiró el suyo ella no lo quiso recogerlo.

A la salida del baile: - - Me la tienes que pagar, te voy a cortar la cabeza y la mano principal.

[Versión 43: Priego de Córdoba, Córdoba (Alcalá Ortiz, 2003: 1132-1133)]

Un domingo por la tarde en la puerta de la iglesia, un novio mató a su novia por la flor de la violeta. La conviaron pa un baile, su madre no la dejó, sin permiso de la madre en el baile se metió.

Como era tan bonita le tiraban los sombreros.

Su novio le tiró el suyo y no quiso arrecogerlo. -A la salida del baile me la tienes que pagar, te he de cortar la cabeza con mi mano prencipal-. Al otro día de mañana ella se estaba painando:

-Retírate de ahí, Antonio, mira que llamo a mi hermano-.

Él se ha arrollado la capa y ha sacado un navajón, 
le ha dado tres puñaladas, le ha pasado el corazón.

La agarraron entre cuatro, la llevaron a la losa

toda vestida de blanco que parecía una rosa.

Y desde la losa al suelo

su padre que estaba allí, la tapó con su sombrero.

Su madre que estaba allí la tapó con su pañuelo.

Llamaron al criminal por ver si la conocía.

- ¿Queréis que no la conozca si ha sido novia mía?

La maté porque ella quiso, que si no, nunca lo hiciera,

porque amores que yo tengo, no quiero que otro los tenga-.

Si el alcalde de este pueblo cumpliera con la justicia,

siete tiritos le diera al que mata a una mocita.

Si el alcalde de Baena cumpliera con su deber,

siete tiritos le diera al que mata a una mujer.

[Versión 44: Priego de Córdoba, Córdoba (Alcalá Ortiz, 2003: 1133-1134)]

En el río Guadalquivir al revolver de una huerta,

un novio mató a la novia por la flor de la violeta.

La convidaron a un baile, su padre dijo que no.

Sin permiso de su padre ella al baile se marchó.

Como era tan bonita tos le tiran el sombrero.

Su novio le tiró el suyo, le dio vergüenza cogerlo.

-A la salida del baile me la tienes que pagar,

te he de cortar la cabeza y la mano prencipal-.

A la salida de baile no le pudo hacer nada,

porque iba de sus amigas un poquito arretirada.

Al otro día de mañana Carmen se estaba peinando,

se le presentó su novio en una capa ocultado.

La cogió y la echó sobre la cama;

en su divina pechera, siete puñalás le daba.

A la una y media en punto el padre vino a almorzar:

— ¿Quién ha sido el asesino? ¿Quién ha sido ese criminal?

Si lo cogiera ahora mismo, lo cosía a puñalás-.

Llamaron al criminal por ver si la conocía:

- ¿No queréis que la conozca si ha sido la prenda mía?

Yo la maté porque quise y porque me dio la gana:

la mujer que tanto he querido otro no la disfrutara-

Al otro día de mañana dos entierros se cruzaban:

él parecía un clavel y ella, una rosa encarnada.

Mira si sería bonita que hasta el mismo enterrador

tiró la pala y el pico: - - A esta no la entierro yo.

[Versión 45: Bélmez de la Moraleda, Jaén (Amezcua, 1991: 36)]

En la cañá de Guartuna ino saben lo que pasó?,

que un novio mató a su novia sin motivo ni razón.

Antonio se llamaba él y celoso por demás,

y ella se llamaba Lola y era de guapa sin par.

La invitaron a un baile su padre no la dejó,

y sin permiso del padre en el baile se metió.

Como era tan bonita le tiraban los sombreros,

su novio le tiró el suyo y no quiso recogerlo.

- A la salida del baile me la tiene que pagar,

te he de cortar la cabeza y la mano principal-. 
A la salida del baile él no le pudo hacer na porque estaba su tía al lado y no se pudo acercar.

A otro día por la mañana Antonio se levantó

Y se fue a casa de su novia en busca de una ocasión.

Sentada a la entrada del cuarto ella se estaba peinando:

—Qué quieres Antonio? ¡Vete!, mira que llamo a mi hermano.

-Lo llames o no lo llames, lo dejes de llamar,

la mala acción que me hicistes me la tienes que pagar-.

Subiendo las escaleras la capa se le caía, y se ha sacado una alfaca y la ha dejado tendida.

Llamaron a la justicia, la llevaron a la losa,

toda vestida de blanco que parecía una rosa.

Allí llamaron a Antonio por ver si la conocía:

- ¿No la voy a conocer si ha sido la novia mía?-.

A las doce menos cuarto vino el padre a merendar:

- ¿Quién ha matado a mi hija? ¿Quién ha sido el criminal?

Si lo cogiera en el acto, lo cosía a puñalás-.

Un rosal cría una rosa y una maceta un clavel,

y un padre cría a una hija sin saber para quién es,

si para algún criminal, si para un hombre de bien.

[Versión 46: Campillo de Arenas, Jaén (Higueras Martínez y Aguilar González, 2000: 142)]

El dieciocho de mayo, señores os voy a contar

que un novio mató a una novia por no salir a bailar.

Como era tan bonita le tiraban los sombreros,

su novio se lo tiró y no quiso arrecogerlo.

- Y a la salida del baile me la tienes que pagar

te he de cortar la cabeza y la mano principal-.

-Ni me cortas la cabeza ni la mano principal,

antes que se termine el baile yo me tengo que marchar-.

A otro día de mañana y apenas se levantó

fue a casa de la novia a cogerla en ocasión.

$\mathrm{Y}$ al subir las escaleras ella se estaba peinando:

-Antonio, vete de aquí, mira que llamo a mi hermano.

-Yo no le temo a tu hermano ni tampoco te temo a ti,

te dije que en mi presencia tú tenías que morir-.

A las tres horas siguientes vino el padre a merendar:

-Dime, hija, quién ha sido, quién ha sido el criminal,

que si lo pillara ahora, lo cosía a puñalás-.

Llamaron al criminal por ver si la conocía:

- ¡Cómo no la iba a conocer si ha sido la novia mía!-

Un rosal cría a una rosa y una maceta un clavel,

y un padre cría a una hija y no sabe pa quién es,

si será para un mal hombre o para un hombre de bien.

[Versión 47: Pontón Alto, Jaén (CLO, 0179r)]

El domingo carnaval de gitana me vestí

y me fui al salón del baile por ver mi novio allí.

Y me dijo: - Gitanilla, ¿quiere usted hacer el favor

de decirme con salero las novias que tengo yo?

- Hombre alto y moreno, quebradito de color,

pero tiene usted una falta, que es algo camelador;

que camela usted a dos niñas más bonitas que un sol. 
Una alta y morena, la otra más rubia que un sol.

No te cases con la rubia que serás un desgraciado, cásate con la morena y serás afortunado.

- iVaya una gitanilla linda que adivina el pensamiento!, si tú fueras castellana trataría de casamiento.

-Y quédate con Dios, Pepe, que mi madre me espera.

Si quieres saber quién soy, soy tu novia la morena-.

El domingo carnaval, señores les voy a contar lo que le pasó a una niña por saber muy bien bailar. Todos le tiran el sombrero, su novio le tiró el suyo, le dio vergüenza cogerlo.

— iA la salida del baile me la tienes que pagar!

¡Te he de cortar la cabeza y la mano principal!-

A otro día por la mañana, Antonio se levantó

y fue a casa de su novia a pillarla en ocasión.

Al subir las escaleras, Dolores se está peinando:

-Quítate de aquí, Antonio, no vaya a venir mi hermano.

- Venga tu hermano o no venga, me la tienes que pagar.

Te he de cortar la cabeza y la mano principal-.

Diciendo estas palabras, l’ha dado tres puñalás.

Una l'ha dado en el lado y otra l'ha dao en el hijal

y otra l'ha dao en el corazón, la que más le hizo penar.

Ya la suben, ya la bajan, ya la ponen en la losa

todo vestida de blanco que parecía una novia.

Ya la suben, ya la bajan, ya la ponen en el suelo;

su novio que estaba allí la tapó con el pañuelo.

Eran las doce y media, sube el padre a merendar:

—QQuién ha sido este valiente? ¿Quién ha sido el criminal?

Si lo viera ahora mismo lo cosía a puñalás-

- La he matado porque quise. La maté porque era mía.

Mujer que yo quiera tanto no quiero que otro se ría.

[Versión 48: Bañares, La Rioja. Riojarchivo, «Un desdén castigado».

http://www.riojarchivo.com/un-desden-castigado/]

El día veinte de abril, mocitas, tener memoria,

que por culpa de los bailes, un novio mató a su novia.

Como era tan rebonita, la tiraban el sombrero.

Antonio la tiró el suyo y no quiso recogerlo.

A otro día a la mañana, Antonio se levantó

para ir a casa de su novia a pillarla en ocasión.

Al subir las escaleras, ella se estaba peinando.

- Vete, Antonio, de mi casa porque va a venir mi hermano.

- Si viene tu hermano, que venga, que yo no quiero yo que amores

que yo haya querido siempre ahora otro se los lleve-

La ha recostado en la cama y, sin decir más palabras,

ha sacado un puñal de oro y le ha dao tres puñaladas.

Ya la suben, ya la bajan, ya la han metido en la losa

toda vestida de blanco que parecía una rosa,

que parecía una rosa, que parecía un clavel.

La madre que tenga una hija y no sepa para quién:

si es para un hombre malvado o es para un hombre de bien.

Por la calle la estación ya nadie quiere pasar

porque vive doña Carmen, la madre del criminal. 
[Versión 49: Sonseca, Toledo (Romero López, 1995: 49-53)]

Allá arribita, arribita, allá arribita en la Almeña, un novio mató a su novia que era la flor de la canela. Como era tan bonita la tiraban el sombrero, y Antonio la tiró el suyo y no quiso recogerlo. - A la salida del baile me las tienes que pagar; te he de cortar la cabeza y la mano más principalA otro día, de mañana, Antonio se levantó, se fue a casa de la novia para aguardar la ocasión. Al subir por la escalera Dolores se está peinando: -Anda, vete de ahí, Antonio, no vaya a venir mi hermano-. Al oír estas palabras se echó mano a su puñal $\mathrm{y}$, al ladito de la cama, tres puñaladas la da.

A las ocho y media en punto viene su padre a almorzar. - ¿Quién te ha matado, hija mía? ¿Quién ha sido el criminal?, que, si lo cogiera ahora, lo cosía a puñalás-.

Ya la suben, ya la bajan ya la ponen en el suelo, su padre que está delante la tapa con el pañuelo. Ya la suben, ya la bajan ya la ponen en la losa, ya la ponen la mortaja toda cubierta de rosas.

Mandaron llamar a Antonio por ver si la conocía:

- ¿Quieres que no la conozca si ha sido la novia mía?

-No la maté por coraje ni tampoco por envidia,

la maté por despreciarme lo mucho que la quería-

Los primeros cinco duros que en la mesa se pusieron

fueron de Antonio Fernández para pagar el entierro.

Las flores del camposanto todas se visten de luto en ver a aquel criminal acompañar al difunto.

Las flores del camposanto todas se visten de negro en ver a aquel criminal acompañar al entierro. 


\section{BIBLIOGRAFÍA*}

Alcalá Ortiz, Enrique (2003): Cancionero popular de Priego. Poesía cordobesa de cante y baile, VI, Priego de Córdoba, Ayuntamiento de Priego de Córdoba.

AMEzCUA, Manuel (1991): «El ciego de los romances y la literatura de cordel en la tradición jiennense», Revista de folklore, 127, pp. 29-36.

ASENSIO GARCÍA, Javier (2004): «La tradición oral calahorrana (I): El romancero», Kalakorikos: Revista para el estudio, defensa, protección y divulgación del patrimonio histórico, artístico y cultural de Calahorra y su entorno, 9, pp. 83-128.

*Asensio García, Javier y Ortiz Viana, Helena: Riojarchivo. Archivo del patrimonio inmaterial de La Rioja. [Riojarchivo] URL: <http://www.riojarchivo.com/>.

Atero Burgos, Virtudes (2003): Manual de encuesta del romancero de Andalucía. Catálogo-Índice, Cádiz, Universidad de Cádiz.

CID, Jesús Antonio (1974): «Romances en Garganta la Olla (Materiales y notas de excursión)», Revista de Dialectología y Tradiciones Populares, 30, pp. 467-527.

*CSIC e Institución Milá y Fontanals, Fondo de Música Tradicional. [FMT] URL: <www.musicatradicional.eu/es/home>.

*DÍAZ GonZÁLEZ, Joaquín: «Fonoteca», Archivo de Tradición Oral. [ATO] URL: <http://www.funjdiaz.net/fono1.php>.

DíAz G. ViAnA, Luis (1983): «La tradición oral, hoy. El ejemplo del Romancero», Revista de Folklore, 31, IIIb, pp. 9-16. URL: <http://www.cervantesvirtual.com/obravisor/la-tradicion-oral-hoy-el-ejemplo-delromancero/html/>.

Escribano Pueo, María Luz, Fuentes VÁzQuez, Tadea y Romero LóPez, Antonio (1995): Romancero granadino de tradición oral. Segunda flor, Granada, Universidad de Granada.

FERrer-SANJuÁn, Agustín Tomás y Bonete PiQueras, Fernando (1993): «Romances de tradición oral. Una recogida de romances en la provincia de Albacete», 17, $219 \mathrm{pp}$.

Higueras MARTíneZ, Francisca y AGUILAR GonZÁLEZ, Lorenzo (eds.) (2000): «Voces para el recuerdo. Canciones y fiestas tradicionales», Sumuntán, 13, pp.131-174.

Manzano Alonso, Miguel (2003): Cancionero de Burgos, III. Cantos narrativos, Burgos, Diputación Provincial de Burgos.

*MAÑERO LOZANO, David (dir./ed.) (2015-): Corpus de Literatura Oral [CLO]. URL: <www.corpusdeliteraturaoral.es>.

MAÑERo LoZANO, David (en prensa): «La buenaventura del carnaval. Tradición oral en un canto narrativo de transmisión moderna», Revista de Filología Española.

MENDOZA DíAZ-MAROTO, Francisco (1990): Antología de romances orales recogidos en la provincia de Albacete, Albacete, Instituto de Estudios Albacetenses de la Excma. Diputación de Albacete / CSIC / Confederación Española de Centros de Estudios Locales (Serie I. Ensayos Históricos y Científicos, 48).

Moreno Moreno, Luis (2016): Romancero de Córdoba: Transcripción y estudio musical de los romances recogidos en la provincia de Córdoba, Tesis Doctoral, Universidad de Córdoba.

\footnotetext{
* Las referencias precedidas de un asterisco han sido referidas en el cuerpo de trabajo y el anexo mediante las abreviaturas indicadas entre corchetes.
} 
PIÑERO RAMÍREZ, Pedro M. (dir.) (1996): Romancero General de Andalucía, I, Romancero de la provincia de Cádiz, ed., introducción e índices de Virtudes Atero Burgos, con la colaboración de Antonio J. Pérez Castellano et alii, Cádiz, Fundación Machado / Universidad de Cádiz / Diputación Provincial de Cádiz.

Piñero RAMíreZ, Pedro M. y ATERo Burgos, Virtudes (1986): Romancerillo de Arcos de la Frontera, Cádiz, Diputación de Cádiz.

ROMERo LóPEZ, María Dolores (1995): Romances y canciones de la villa de Sonseca. Serie VI, Temas Toledanos, Toledo, Diputación Provincial de Toledo.

SALAZAR, Flor (1999): El romancero vulgar y nuevo, Madrid, Fundación Ramón Menéndez Pidal y Seminario Menéndez Pidal de la Universidad Complutense.

TRAPERO, Maximiano (1991): Romancero de Fuerteventura, transcripción y estudio de la música de Lothar Siemens Hernández, Madrid, Caja Insular de Ahorros de Canarias.

*TRAPERO, Maximiano y GIRÓN, Alicia: Archivo de literatura oral de Canarias. [ALOC] URL: <mdc.ulpgc.es/cdm/landingpage/collection/asmtloc>.

Trapero, Maximiano, LEÓN FELIPE, Benigno y MonROY CABALlero, Andrés (eds.) (2016): Romancero general de Tenerife, con estudio de la música de Lothar Siemens Hernández, Tenerife, Ediciones Idea.

Fecha de recepción: 2 de mayo de 2019

Fecha de aceptación: 28 de mayo de 2019

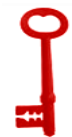

